\title{
Caloric Variability of Corbicula fluminea (Mollusca, Bivalvia) in Rosana Reservoir, Brazil
}

\author{
Yara Moretto Bagatini $^{*}$, Evanilde Benedito-Cecilio ${ }^{2}$ and Janet Higuti $^{1,2}$ \\ ${ }^{1}$ Pós-Graduação em Ecologia de Ambientes Aquáticos Continentais; Universidade Estadual de Maringá; \\ ymorettob@hotmail.com; ${ }^{2}$ Núcleo de Pesquisas em Limnologia, Ictiologia e Aquiicultura; Universidade Estadual de \\ Maringá; Av. Colombo, 5790; 87020-900; Maringá - PR - Brasil
}

\begin{abstract}
The purpose of the present study was to investigate temporal and longitudinal variation of caloric density of Corbicula fluminea in Rosana Reservoir. Significant differences concerning the caloric density of $\mathrm{C}$. fluminea were observed throughout the year at the three reservoir sites. The caloric density variation during the year was probably related to reproductive activity, which demanded higher allocation of energy in certain period. The food source used by this species might be an important factor in the caloric value temporal and spatial variation of $\mathrm{C}$. fluminea in Rosana Reservoir.
\end{abstract}

Key words: $C$. fluminea, caloric content, temporal and longitudinal variation, reservoir

\section{INTRODUCTION}

In tropical regions, studies about caloric density have been carried out mainly on ichthyofauna (Ngan et al., 1993; Dória and Andrian, 1997; Benedito-Cecílio et al., 2004) and aquatic insects (Higuti et al., 2003). Investigations of the bioenergetics of mollusks have been performed in other countries, mostly, on marine species (Stanczykowska and Lawacz, 1976; Clarke et al., 1985; Dauvin and Joncourt, 1989; Williams and McMahon, 1989; Beukema, 1997; McMahon, 2000).

Corbicula fluminea (Müller, 1774) is a native species from Southeast Asia and has r-strategist characteristics, in other words, to present high fecundity, short life span and high rate of growth and dispersion (McMahon, 1982; Ortmann and Grieshaber, 2003). Such factors have made it a successful colonizer of most freshwater habitats, adapting to a large variability of environmental conditions (McMahon, 2000). They are widely distributed in riverine systems (Cataldo and Boltovskoy, 1999; Rajagopal et al., 2000) and reservoirs (Layzer et al., 1993; McMahon, 2000). In Brazil, they were first observed in 1970 by Veitenheimer-Mendes (1981), and subsequently by others (Callil and Mansur, 2002; Takeda et al., 2004; Bagatini, 2004).

C. fluminea has caused a series of environmental and economical impacts (Aldridge and Müller, 2001). This mollusk species strongly influences aquatic ecosystem, since it obtains its energy directly from primary producers (Vaughan and Hakenkamp, 2001), transferring it to other links of the trophic chain, including some species of fishes, aquatic birds and mammals (McMahon, 2000). Dry matter caloric content measurements have been used mainly to verify energetic relationships in environments (Verduin, 1961; Grant, 1996).

${ }^{*}$ Author for correspondence 
Thus, the present study aim to investigate temporal and longitudinal variation of caloric density of $C$. fluminea in Rosana Reservoir.

\section{STUDY AREA}

The Rosana Reservoir Hydroelectric Power Plant dam is located in the Paranapanema River between
Rosana (State of São Paulo) and Diamante do Norte (State of Paraná). The reservoir has an area of $220 \mathrm{~km}^{2}$ and is about 25 meters depth. Three sampling sites were established through the longitudinal axis of the reservoir, lotic site $\left(22^{\circ} 39^{\prime} 05^{\prime}\right.$ ' $S$ and $052^{\circ} 10^{\prime} 52^{\prime}$ ' $\left.\mathrm{W}\right)$, intermediate site (22 $36^{\circ} 57^{\prime \prime} \mathrm{S}$ and $\left.052^{\circ} 29^{\prime} 20^{\prime \prime} \mathrm{W}\right)$ and lentic site (22 $35^{\circ} 24^{\prime \prime}$ 'S and $\left.052^{\circ} 49^{\prime} 51^{\prime \prime} \mathrm{W}\right)$ (Fig. 1).

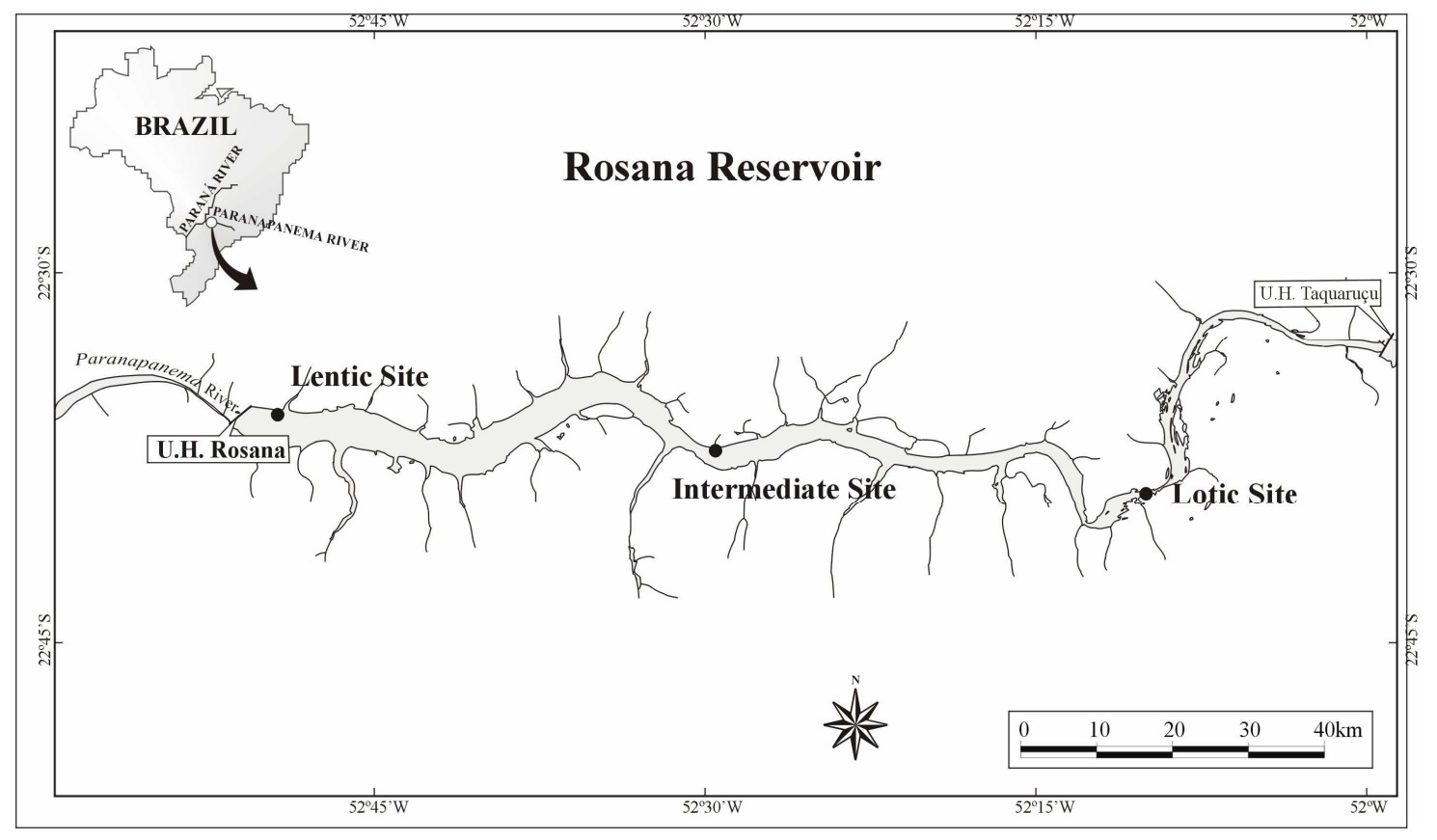

Figure 1 - Rosana Reservoir sites at Paranapanema River

\section{MATERIALS AND METHODS}

\section{Data collection}

The collection of $C$. fluminea was carried out quarterly from March to December 2002, on the shore of the lotic, intermediate and lentic Rosana Reservoir sites. At least three samples of $C$. fluminea were collected using a modified Petersen grab $\left(0.018 \mathrm{~m}^{2}\right)$ and preserved in liquid nitrogen $\left(-196^{\circ} \mathrm{C}\right)$.

\section{Caloric content determination}

Considering the $C$. fluminea $(\mathrm{n}=193)$ specimens, the calorimetric analyses were carried out based on a minimum of three samples, in order to identify their caloric variability (Flat and Diana, 1985; Economids et al., 1981). In the laboratory, the valves were size measured and the bodies of two or three individuals with similar length were grouped together to form a sample with a dry weight above $0.025 \mathrm{~g}$ (minimum weight for combustion). The samples were dried in oven at $60^{\circ} \mathrm{C}$ for $24 \mathrm{~h}$. The calorie per gram of the organisms was determined from the dry biomass, using a Parr 1261 calorimeter. A two-way ANOVA was performed using the caloric values of $C$. fluminea at different sites and months.

\section{RESULTS}

Decrease in the mean caloric content of $C$. fluminea was observed during the year, with very close values in September and December (Fig. 2a). The mean highest caloric density was recorded at the intermediate site $(5000 \mathrm{cal} / \mathrm{g})$, followed by the lotic $(4920 \mathrm{cal} / \mathrm{g})$ and lentic $(4800 \mathrm{cal} / \mathrm{g})$ ones (Fig. 2b). Differences in the caloric content of $C$. 
fluminea at the three sites $(\mathrm{p}<0.05 ; \mathrm{F}=8.87)$ and over the months ( $\mathrm{p}<0.05 ; \mathrm{F}=7.84$ ) were significant. However, the interaction between sites and months was also significant $(\mathrm{p}<0.05 ; \mathrm{F}=$ 7.13) suggesting that both sites and months might influence the caloric content of $C$. fluminea.
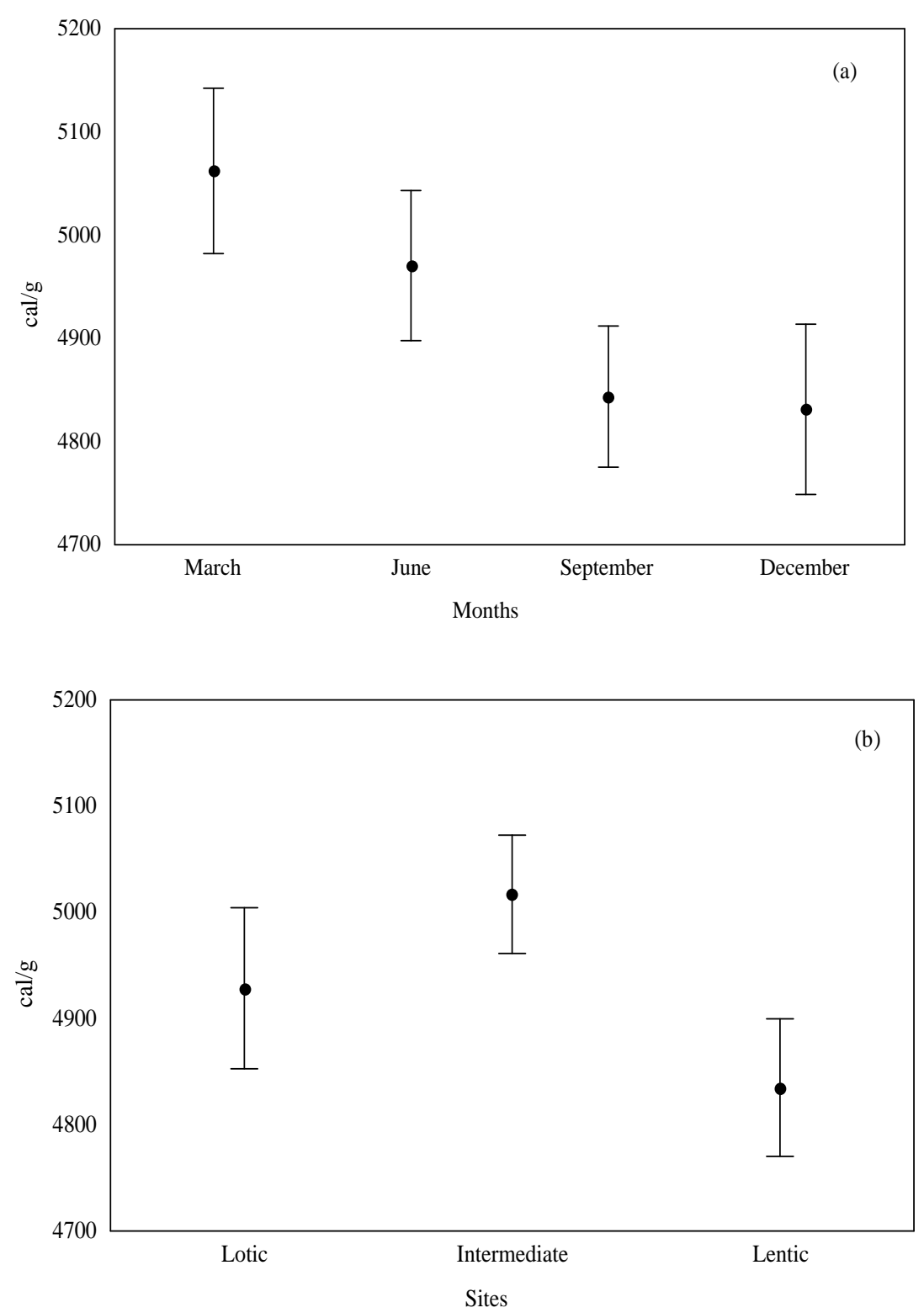

Figure 2 - Caloric content per gram of dry weight of $C$. fluminea in the Rosana Reservoir (a) Months; (b) Sites.

\section{DISCUSSION}

The variation in the energy of $C$. fluminea during the year might be related to its reproductive period. Kraemer and Galloway (1986) reported that the reproductive process generally occurred during the coldest months, since with the increase in water temperature, the sequence of reproductive development was interrupted. Also, the occurrence of only one annual reproductive period was recorded in South America (Bacia do Plata) (Cataldo and Boltovskoy, 1999). In Rosana Reservoir, the caloric density, in general, was higher in March and June. According to Bagatini (2004), these months precede the assumed reproductive period of $C$. fluminea (July and 
August). This might be related to large acquisition of energy for the reproductive period, and consequent decrease in caloric density over the next months (September and December).

According to Willians and McMahon (1989), the biomass rises and, consequently, so does the energetic value of $C$. fluminea, coinciding with the period of higher energetic demand for reproduction. Experiments carried out by McMahon and Willians (1986) with C. fluminea also evidenced seasonal changes concerning the condition of the tissues of this bivalve. The results obtained in Rosana Reservoir were in agreement with the above, since high caloric density was observed in the beginning of the year, followed by a decrease in caloric value (from September onwards), which probably occurred after the liberation of larvae into the water.

C. fluminea is a filterer species and its biomass is expected to consist basically of carbon from phytoplankton or even from bacterioplankton (Vaughan and Hakenkamp, 2001). Thus, the energetic value of $C$. fluminea could be influenced by available food source. Low phytoplankton biomass was recorded in Rosana Reservoir (Train et al., 2005); however, the energy of $C$. fluminea probably was kept by algae, besides the high biomass of the bacterioplankton (Pagioro et al., 2005), which was also a source of energy for organisms specialized in feeding on finely particulate detritus (Smith et al., 1982). This availability of food demonstrated that the energetic content might change temporally and spatially. In spite of low phytoplankton biomass in Rosana Reservoir (Train et al., 2005), the higher caloric values of $C$. fluminea were in agreement with the temporal and spatial phytoplankton variation, suggesting algae as main energetic source of this species.

Similar results were also reported for Mytilus chilensis (Bivalvia), in which the energetic content change with available food, growth and reproduction (Duarte et al., 1980).

Some studies have also demonstrated that species of fish benthophagous feed on $C$. fluminea (Montalto et al., 1999; Gaspar da Luz et al., 2002). Thus, the exotic species, $C$. fluminea, can take part in the trophic chain, especially because of high biomass in freshwater environments. The present study, although restricted to Rosana Reservoir, revealed that the invasive species $C$. fluminea could have an important role in the transfer of energy.

\section{ACKNOWLEDGMENTS}

The authors thank Dr. Cláudia Callil and Dr. Rosemara Fugi for their valuable suggestions; and to all others who assisted during the field sampling. Thanks are also due to Jaime Lopes Pereira for the map; $\mathrm{CNPq}$ for the financial support and Nupélia for the logistic support.

\section{RESUMO}

O objetivo deste estudo foi investigar a variação temporal e longitudinal da densidade calórica de C. fluminea no reservatório de Rosana. Diferenças significativas na densidade calórica de $C$. fluminea foram observadas ao longo do ano e nas três estações do reservatório. A variação na densidade calórica de $C$. fluminea, durante $\mathrm{o}$ ano, provavelmente foi relacionada à atividade reprodutiva, que exige uma maior alocação de energia em determinado período. $\mathrm{O}$ recurso alimentar utilizado por esta espécie pode ser um importante fator na variação temporal e espacial do valor calórico de $C$. fluminea no reservatório de Rosana.

\section{REFERENCES}

Aldridge, D. C. and Müller, S. (2001), The Asiatic clam, Corbicula fluminea, in Britain: current status and potential impacts. J. Conchol., 37, 177-183.

Bagatini, Y. M. (2004), Biomassa e relações energéticas de Corbicula fluminea (Muller, 1774) (Molusca, Bivalvia) no reservatório de Rosana. Dissertação (Mestrado em Ecologia de Ambientes Aquáticos Continentais), Centro de Ciências Biológicas, Universidade Estadual de Maringá, Maringá.

Benedito-Cecilio, E.; Dourado, E. C. S.; Lopes, C. A.; Faria, A. E. A.; Pinheiro, R. P.; Bonicci, P.; Pereira, A. L. and Morimoto, M. (2004), Estimate of the energy of producers and consumers in the Upper Paraná River floodplain. In- Structure and functioning of the Paraná River and its floodplain, eds. A. A. Agostinho; L. Rodrigues, L. C. Gomes, S. M. Thomaz and L. E Miranda, EDUEM/Maringá. pp. 145-150. 
Beukema, J. J. (1997), Caloric values of marine invertebrates with an emphasis on the soft parts of marine bivalves. Oceanogr. Mar. Biol: annu. rev., 35, 387-414.

Callil, C. T. and Mansur, M. C. D. (2002), Corbiculidae in the Pantanal: history of invasion in southeast and central South America and biometrical data. Amazoniana, Manaus, MPI für Limnologie, AG Tropenökologie, Pön, INPA, 17, 153-167.

Cataldo, D. and Boltovskoy, D. (1999), Population dynamics of Corbicula fluminea (Bivalvia) in the Paraná River Delta (Argentina). Hydrobiologia, Netherlands, Kluwer Academic Publisher, 380, 153163.

Clarke, A.; Clarke, M. R.; Holmes, L. J. and Waters, T. D. (1985), Caloric value and elemental analysis of eleven species of oceanic squids (Mollusca: Cephalopoda). J. Mar. Biol Assoc. U.K, 65, 983-986.

Dauvin, J. C. and Joncourt, M. (1989), Energy values of marine benthic invertebrates from the western English Channel. J. Mar Biol Assoc. U.K., 69, 589595.

Doria, C. R. C. and Andrian, I. F. (1997), Variation in energy content of somatic and reproductive tissues related to the reproductive cycle and feeding of female Pimelodus maculatus Lacépède, 1803 (Siluriformes, Pimelodidae) and Schizodon borellii Boulenger, 1895 (Characiformes, Anostomidae). Revista Unimar, 9, 421-437.

Duarte, W. E.; Jara, F. and Moreno, C. A. (1980), Contenido energético de algunos invertebrados bentônicos de la costa de Chile y fluctuación annual em Mytilus chilensis Hupe 1854. Bolm Inst. Oceanog., 29, 157-162.

Economids, P. S.; Pantis, J. and Margaris, N. S. (1981), Caloric content in some freshwater and marine fishes from Greece. Cybium, $3^{\text {a }}$. série, 5, 97-100.

Flat, L. E. and Diana, J. (1985), Seasonal energy dynamics of the alewife in Southeastern Lake Michigan. Trans. Am. Fish. Soc., 114, 328-337.

Gaspar da Luz, K. D.; Fugi, R.; Abujanra, F. and Agostinho, A. A. (2002), Alterations in the Pterodoras granulosus (Valenciennes, 1833) (Osteichthyes, Doradidae) diet due to the abundance variation of a bivalve invader species in the Itaipu reservoir, Brazil. Acta Scientiarum, 24, 427-432.

Grant, J. (1996), The relationship of bioenergetics and the environment to the field growth of cultured bivalves. J. Exp. Mar. Biol. Ecol., 200, 239-256.

Higuti, J.; Bagatini, Y. M.; Takahashi, M. A.; Zviejkovski, I. P.; Dias, V. G. and Benedito-Cecilio, E. (2003), Efeito do estado trófico de reservatórios paranaenses sobre o conteúdo calórico de insetos aquáticos. In- Workshop Produtividade em Reservatórios e Bioindicadores, eds. L. Rodrigues, A. A. Agostinho, L. C. Gomes and S. M. Thomaz. Maringá: UEM/Nupelia, pp. 153-159.
Kraemer, L. R. and Galloway, M. L. (1986), Larval development of Corbicula fluminea (Müller) (Bivalvia: Corbiculacea): an appraisal of its heterochrony. Am. Malacol. Bull., 4, 61-79.

Layzer, J. B., Gordon M. E. and Anderson, R. M. (1993), Mussels: the forgotten fauna of regulated rivers. A case study of the Caney Fork river. Regul. Riv.: Res. and Manag., 8: 63-71.

McMahon, R. F. (1982), The occurrence and spread of the introduced Asiatic freshwater clam, Corbicula fluminea (Muller), in North America: 1924-1982. Nautilus, 96, 134-141.

McMahon, R. F. and Willians, C. J. (1986), A reassessment of growth rate, life span, life cycle and population dynamics in a natural population and caged individuals of Corbicula fluminea (Muller) (Bivalvia: Corbiculacea). Am. Malacol. Bull. Special Edition, 2, 151-166.

McMahon, R. F. (2000), Characteristics invasives of the freshwater bivalve, Corbicula fluminea. InNonindigenous Freswater organisms: vectors, biology and impacts, eds. R. Claudi and J. H. Leach, Lewis Publisher, New York, pp. 315-346.

Montalto, L.; Oliveros, O. B.; Ezcurra De Drago, I. and Demonte, L. D. (1999), Peces del rio Paraná medio predadores de una especie invasora: Limnoperna fortunei (Bivalvia, Mytilidae). FACIB, 3, 85-101.

Ngan, P. V.; Gomes, V.; Morais, D. M. and Passos, M. J. A. (1993), Estudos bioenergéticos de animais marinhos costeiros. I. Paralonchurus brasiliensis (Perciformes, Scianidae). Bolm. Inst. Oceanogr., 10, 199-215.

Ortmann, C. and Grieshaber, M. K. (2003), Energy and valve closure behavior in the Asian clam Corbicula fluminea. J. Exp. Biol., 206, 4167-4178.

Pagioro, T. A.; Velho, L. F. M.; Lansac-Tôha, F. A.; Pereira, D. G. and Nakamura, A. K. S. (2005), Influência do grau de trofia sobre os padrões de abundância de bactérias e protozoários planctônicos em reservatórios do estado do Paraná. In- Biocenose em Reservatórios: padrões espaciais e temporais, eds. L. Rodrigues; S. M. Thomaz; A. A. Agostinho and L. C. Gomes. Maringá: UEM/Nupelia, pp. 47-56.

Rajagopal, S., Van Der Velde, G. and Bij De Vaate, A. (2000), Reproductive biology of the Asiatic clams Corbicula fluminalis and Corbicula fluminea in the river Rhine. Arch. Hydrobiol., 149, 403-420.

Smith, G. A.; Nickels, J. S.; Daviews, W. M.; Martz, R. F.; Findlay, R. H. and White, D. C. (1982), Perturbations in the biomass, metabolic activity, and community structure of the estuarine detrital microbiota: resource portioning in amphipod grazing. J. Exp. Mar. Biol. Ecol., 64, 125-143.

Stanczykowska, A. and Lawacz, W. (1976), Caloric value of the Dreissena polymorpha (Pall.) dry body weight in some Mazurian Lakes. Pol. Arch. Hydrobiol., 23, 271-275. 
Takeda, A. M., Fujita, D. S. and Fontes Jr, H. M. (2004), Perspectives on exotic bivalves proliferation in the Upper Paraná River Floodplain. In- Structure and functioning of the Paraná River and its floodplain, eds. A. A. Agostinho, L. Rodrigues, L. C. Gomes, S. M. Thomaz and L. E. Miranda, Maringá/ EDUEM, pp. 97-100.

Train, S.; Jati, S.; Rodrigues, L. C. and Pivato, B. M. (2005). Distribuição espacial e temporal do fitoplâncton em três reservatórios da bacia do rio Paraná. In- Biocenose em Reservatórios: padrões espaciais e temporais, eds. L. Rodrigues; S. M. Thomaz; A. A. Agostinho and L. C. Gomes. Maringá:UEM/Nupelia, pp.73-85.

Vaughn, C. C. and Hakenkamp, C. C. (2001), The functional role of burrowing bivalves in freshwater ecosystems. Freshw. Biol., 46, 1431-1446.

Veitenheimer-Mendes, I. L. (1981), Corbicula manilenssis (Philippi, 1844), molusco asiático, na bacia do Jacuí e do Guaíba, Rio Grande do Sul, Brasil (Bivalvia, Corbiculidae). Iheringia, Ser. Zool., 60, 63-74.

Verduim, J. (1961), Caloric content and available energy in plant matter. Ecology, 42, 515.

Williams, C. J. and McMahon, R. F. (1989), Annual variation of tissue biomass and carbon and nitrogen content in the freshwater bivalve Corbicula fluminea relative to downstream dispersal. Can. J. Zool., 67, 82-90.

Received: June 06, 2005; Revised: December 29, 2005; Accepted: September 06, 2006. 